\title{
Cambridge University versus Hebrew University: The impact of letter transposition on reading English and Hebrew
}

\author{
Hadas Velan AND RAM Frost \\ Hebrew University, Jerusalem, Israel
}

\begin{abstract}
Is reading similarly affected by letter transposition in all alphabetic orthographies? "The Cambridge University effect," demonstrating that jumbled letters have little effect on reading, was examined using rapid serial visual presentation (RSVP) in English and in Hebrew. Hebrew-English bilinguals were presented sentences in both languages containing words with transposed letters. Sentences were presented rapidly on the screen word by word, and participants had to reproduce the sequence of words perceived. We found a marked difference in the effect of transpositions in the two languages. In English, transpositions had little effect on performance, whereas in Hebrew, performance deteriorated dramatically for words with transposed letters. The differential effects of transposition are accounted for by the difference in lexical organization in Hebrew and in English, suggesting that models of reading in alphabetic orthographies may be language specific.
\end{abstract}

The effect of letter transposition on reading is attracting significant attention in visual word recognition research. In recent years, several studies have consistently reported robust form-orthographic priming effects when primes and targets shared the identity of individual letters but in a different order (e.g., gadren priming garden). Masked priming with transposed letters was reported in several Indo-European languages such as English (e.g., Lupker \& Perea, 2003), French (Schoonbaert \& Grainger, 2004), and Spanish (Perea \& Lupker, 2004). The finding that robust form-orthographic priming can be obtained even with changes in letter order has revolutionized the modeling of visual word recognition. It presented immense difficulties for slot-based coding computational models, which encode letter position in absolute terms - for example, the interactive activation (IA) model by McClelland and Rumelhart (1981) or the dual-route cascaded (DRC) model by Coltheart, Rastle, Perry, Langdon, and Ziegler (2001). Consequently, a new generation of computational models that focus on context-sensitive coding of relative letter position has emerged (e.g., Grainger \& Van Heuven, 2003; Grainger \& Whitney, 2004; Whitney, 2001, and see Schoonbaert \& Grainger, 2004, for a discussion).

Perhaps the most dramatic demonstration of how reading is resilient to letter transposition is the following paragraph that has been circulating via the Internet, especially in the reading research community:

Aoccdrnig to rscheearch at Cmabrigde Uinervtisy, it deosn't mttaer in waht oredr the ltteers in a wrod are, the olny iprmoetnt tihng is taht the frist and lsat ltteer be at the rghit pclae. The rset can be a total mses and you can sitll raed it wouthit porbelm. Tihs is bcuseae the huamn mnid deos not raed ervey lteter by istlef, but the wrod as a wlohe.

We should note upfront that the original text does not refer to any true research project that was ever conducted at the University of Cambridge. We cannot know precisely why the author who drafted the above paragraph chose the name "Cambridge University effect" for this phenomenon that effectively demonstrates the impact of jumbled letters, or lack of such impact, and the name has stuck. Since its first appearance in 2003, the Cambridge Univesity effect has become somewhat of an urban legend. The English text has been translated to French, Spanish, Italian, Dutch, German, Danish, Finnish, Icelandic, Portuguese, Swedish, Russian, Hungarian, Irish, Polish, Albanian, and Hebrew. Apparently the original demonstration of the effect of letter randomization on skilled reading (or rather lack of it) belongs to Rawlinson, 1976 (and see Rawlinson, 1999, for a reference to it). In an unpublished dissertation, he showed that letter randomization in the middle of the word had little effect on the ability of skilled readers to understand the printed text (see Davis, 2003, for a web page devoted to the effect). A recent study monitoring eye movements showed that, indeed, some transpositions are easy to read, but others do pose some difficulty (Rayner, White, Johnson, \& Liversedge, 2006). Nevertheless, given the significant attention that the Cambridge University effect has drawn, the meager volume of systematic empirical research it has created is remarkable. This may be due to the inherent problems in objectively measuring the psychological difficulty or ease of reading, while controlling all possible factors that affect text comprehension.

R. Frost, frost@mscc.huji.ac.il 
The present study explores an experimental method to empirically investigate the impact of letter transposition on sentence reading, in order to examine the effect from a cross-linguistic perspective. Our goal was to investigate whether the impact of letter transposition (or lack of it) on reading is indeed characteristic of any alphabetic orthography, or whether it reflects the specificities of the lexical structure of a given language. In the latter case, the implications for models of visual word recognition would be far reaching, as it would mean that such models are language specific.

Our study focused on reading in Hebrew-English bilinguals. Investigating effects of letter transposition in Hebrew versus English is of major theoretical interest. On the one hand, Hebrew, like English, has an alphabetic orthography. Although some vowels, such as /a/ or /e/ may not appear in print, in principle, the 22 letters of the Hebrew alphabet represent the phonemes of the language, as is the case in English. Similar to other Indo-European languages, reading in Hebrew has been shown to involve fast conversion of graphemes to phonemes (see Frost, 1995, for a discussion). From a morphological perspective, however, there are marked differences between Hebrew and English. Hebrew is a Semitic language, where most words can be decomposed into two abstract morphemes: a triconsonantal root, which represents the core meaning of the word, and a word pattern, which can be a sequence of vowels and/or consonants and represents morphosyntactic information. In the present context, the most salient feature of Semitic languages' morphology is the special manner in which morphemic units are combined to form words. Roots and word patterns are not appended to one another linearly, as in languages like English; rather, the consonants of the root are intertwined with the phonemes (and therefore, the corresponding letters) of the word pattern (see Frost, Forster, \& Deutsch, 1997, for a detailed discussion).

Numerous studies examining visual word recognition in Hebrew have suggested that, in the course of word recognition, words are decomposed into their constituent morphemes, and that these morphemic units determine lexical organization and govern lexical access (e.g., Deutsch, Frost, \& Forster, 1998; Frost et al., 1997). In a recent study, Frost, Kugler, Deutsch, and Forster (2005) have further argued that the lexical architecture of Hebrew is primarily determined by morphological and not by orthographic characteristics. According to this view, lexical space in Hebrew is organized so that all words derived from the same root are clustered together; therefore, the initial stage of word recognition entails the extraction of the root letters. These conclusions were supported by the persistent finding that no form-orthographic priming could be obtained in Hebrew, and that masked formpriming is unaffected by neighborhood density, which is in sharp contrast to the case in Indo-European languages such as English, French, or Spanish. If lexical access in Hebrew is indeed based on a preliminary search of a triliteral root entry, then the sensitivity of Hebrew readers to letter transposition may be significantly increased relative to readers of Indo-European languages. The a priori support for such a hypothesis is based on simple combinatorial arguments. The Hebrew language has a listing of about 3,000 triconsonantal roots (Ornan, 2003), which are represented by the 22 letters of the alphabet. The immediate combinatorial implication is that many roots have to share the same set of three consonants (or letters) but in a different order. For example, the letter order of the root S.L.X ("to send"), can be altered to produce the root X.L.S ("to dominate"), X.S.L ("to toughen"), and L.X.S ("to whisper"). In fact, one can hardly find a triconsonantal root that does not share its set of three letters with other roots. This leads us to the hypothesis of our present investigation: If lexical access in Hebrew requires the identification of a specific root, then letter order is critical, and the processing system should not be able to tolerate transpositions involving root letters. This is because all derivations of X.L.S, for example, need to be differentiated from those of S.L.X, L.X.S, or X.S.L. If our hypothesis is correct, the Cambridge University effect will not work in a Semitic language, such as Hebrew. The effect could then be taken to reflect the specific characteristics of Indo-European languages, rather than a general property of the visual processing of words in alphabetic orthographies.

We investigated this intriguing possibility by examining reading performance of Hebrew-English bilinguals, using rapid serial visual presentation (RSVP; see Potter, 1984). Subjects were presented with 20 sentences in English and 20 in Hebrew, 10 of which had transposed-letter words, and 10 of which were intact. The sentences were presented on the screen word by word and each word appeared for $200 \mathrm{msec}$. Following the final word, subjects had to vocally produce the entire sentence. We were interested in the relative level of performance in Hebrew and in English on sentences which involved the transposition of letters; these were compared with the presentation of the intact sentences. We measured how often subjects could recover and produce the correct words in English and in Hebrew from the transposed version and whether subjects were at all aware of the transposition manipulation in each language.

\section{METHOD}

\section{Subjects}

The subjects were 28 students at the Hebrew University, who were all Hebrew-English balanced bilinguals (both English and Hebrew are spoken at home). Subjects' proficiency in English and in Hebrew was verified through self-report in a questionnaire that assessed their level in speaking, writing, and reading in both languages.

\section{Stimuli}

The stimuli consisted of 20 sentences in Hebrew and 20 in English, which were all 7 to 13 words long. Each sentence was either presented intact or with three words that had letter transpositions. Thus, there were $60(20 \times 3)$ target words that were transposed in each language (see sentences in the Appendix). Target words within a given sentence were never consecutive.

Clearly, as in any cross-linguistic study, there are inherent problems in equating stimuli, given the idiosyncratic structural properties of the investigated languages. For example, function words are independent words in English, while they are clitics in Hebrew, and 
words in Hebrew are on average shorter than in English, as some of the vowel information is not represented in print. Such differences cannot be avoided. For the purpose of the present study, we were especially concerned with factors that have been demonstrated to affect letter transposition effects. These mainly involve the identity and position of transposed letters. We therefore matched the letter transposition criteria in the two languages as follows: Given the relative importance of initial and final letters (e.g., Rayner et al., 2006), in both languages, transpositions only involved middle letters. Due to the difference in transposing vowels in comparison with consonants (Perea \& Lupker, 2004), in both languages only consonants were transposed. All transpositions in Hebrew or English involved two adjacent consonants. To avoid any confound with lexicality, for both English and Hebrew material, letter transpositions resulted in nonwords only. Thus, in Hebrew, the letters of the root were transposed, creating a nonexisting root, and then reembedded in the original word pattern creating the nonword. Since we ensured that only adjacent letters were transposed in both languages, all of the letters of the root were continuous, so that the continuity of the letters of the root was not orthographically compromised by letters belonging to the word pattern. Consequently, transpositions both in Hebrew and in English did not result in the crossing of morphemic boundaries (see Christianson, Johnson, \& Rayner, 2005, for a discussion). Words involving transpositions were at least four letters long, with an average of five and eight letters for Hebrew and for English, respectively. The number of phonemes did not differ significantly in the two languages. Finally, in the two languages we employed target words with similar neighborhood density to aim for an identical number of competing orthographic neighbors (mean of 1.3 and 1.8 in English and in Hebrew, respectively $[t(118)=0.161, p<.533]$.

\section{Design}

Two experimental lists were constructed, each list contained ten intact sentences and ten transposed sentences in each language. Sentences that were intact in List A were transposed in List B, and vice versa. All sentences in a given language were presented in one block; half of the subjects were first tested with the Hebrew material, whereas the other half viewed the English material first.

\section{Procedure}

The procedure was identical in both the Hebrew and the English blocks. The experimenter pressed the space bar to initiate the sentence presentation. Each sentence was then presented word by word, each word appeared on the center of the screen for $200 \mathrm{msec}$. Subjects were informed ahead of time that some sentences may involve letter transposition. Nonetheless, they were instructed to identify which sentences contained transposed-letter words and to produce these sentences without replicating the actual transpositions. Following the final word of each sentence, subjects repeated the sequence of words that they had perceived and then explicitly noted whether they have detected any letter transposition in the sentence. All answers were recorded by the experimenter.

\section{RESULTS}

For each subject in each language we calculated the overall percentage of correct report of words in normal sentences, which functions as a baseline performance (left bars of figures), as well as in the sentences containing transpositions (right bars of figures). The left side of Figure 1 presents participants' performance in reading all the words of the Hebrew and the English sentences (including target words), whereas the right side of Figure 1 focuses only on the reading of the 60 target words in each language, which served for the transposition manipulation. Both measures reflect subjects' performance given our RSVP parameters and complement each other.

As can be seen in both parts of the figure, subjects' baseline performance in word identification was high and very similar in the two languages: Eighty-six percent of all words and $82 \%$ of the target words were reported correctly in English; similarly, $81 \%$ of all words and $84 \%$ of the target words were reported correctly in Hebrew. This outcome suggests that the material employed in Hebrew and in English was indeed very similar in terms of reading complexity for our balanced bilinguals. Turning to the impact of letter transposition, it is clear that transpositions affected reading very differently in the two languages. In English, letter transposition had no effect, and performance under normal and transposed-letter presentation was virtually identical. In contrast, a dramatic drop in performance was observed for Hebrew, when sentences included words with transposed letters. Correct report of all words was reduced from $81 \%$ in normal presentation to $62 \%$ for the transposed letter presentation. A two-way ANOVA with the main factors of language (English, Hebrew) $\times$ transposition (normal text, transposed text) revealed this interaction to be significant $[F(1,27)=29.4$,
A

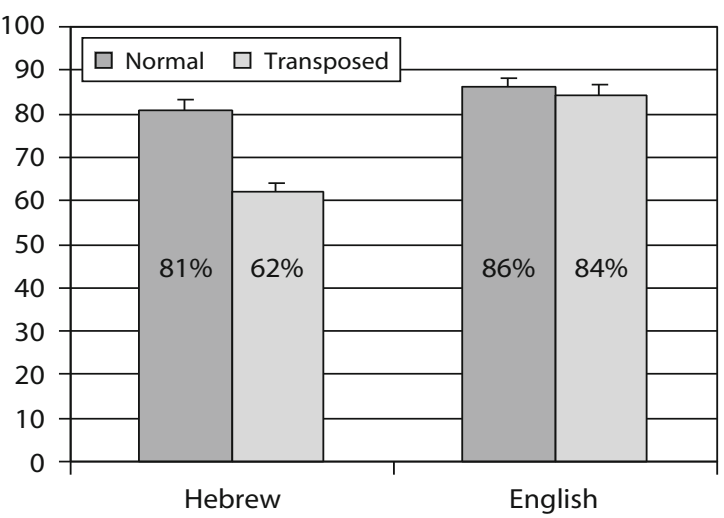

B

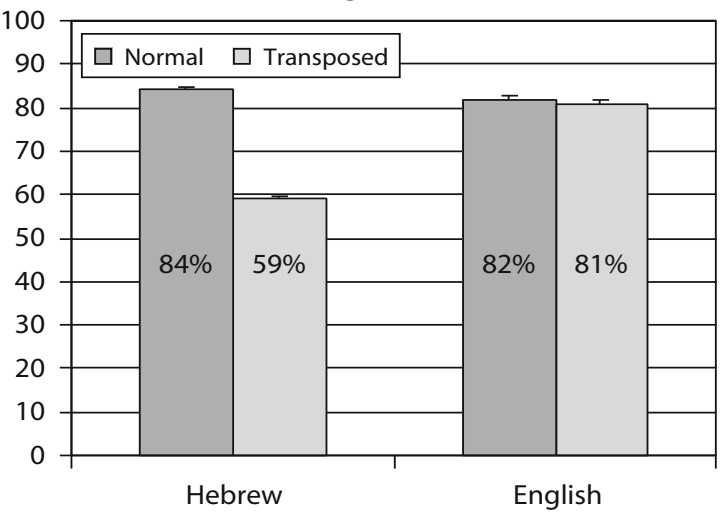

Figure 1. Percent report of all words and target words $(n=60)$ in English and in Hebrew in normal (left bar) and in transposed (right bar) text. Upper bars represent the standard errors of the means. 
Table 1

Probabilities of Hits and False Alarms in Detecting Letter

Transpositions in English and in Hebrew, With $d^{\prime}$ Scores

\begin{tabular}{cccc}
\hline & \multicolumn{2}{c}{ Probabilities } & \\
\cline { 2 - 3 } & Hits & False Alarms & $d^{\prime}$ Scores \\
\hline English & .49 & .19 & 0.86 \\
Hebrew & .88 & .09 & 2.51 \\
\hline
\end{tabular}

$\left.M S_{\mathrm{e}}=1992, p<.001, \eta_{\mathrm{p}}^{2}=0.52\right]$. Similarly, considering target words only, correct recognition of target words dropped from $84 \%$ in normal text to $59 \%$ in transposed text. Again, two-way ANOVA for language and transposition revealed this interaction to be significant for both subjects and stimuli $\left[F_{1}(1,27)=29.5, M S_{\mathrm{e}}=320, p<\right.$ $.001, \eta_{\mathrm{p}}^{2}=0.52 ; F_{2}(1,118)=57.5, M S_{\mathrm{e}}=339, p<.001$, $\left.\eta_{\mathrm{p}}^{2}=0.33\right]$.

One possible argument that could be raised to account for these findings is that perhaps the differences in probabilities of recovery from transposition in English and in Hebrew had to do with the saliency of the semantic context in the two languages. Or perhaps it had to do with the number of competing alternative reading solutions which may not be reflected by neighborhood density measures, factors that are very difficult, if not impossible, to control. For this reason, we sought a measure that did not focus on recovery from transposition, but simply compared the mere detection of letter transposition in the two languages. As we asked participants, following each sentence, to report whether they had detected a letter transposition in any word in the sentence or not, we were able to calculate the $d^{\prime}$ in English and in Hebrew (a measure derived from signal-detection theory, which describes subjects' sensitivity in detecting the signal - that is, the letter transposition, where $d^{\prime}=0$ reflects chance-level detection; see Green \& Swets, 1966). Table 1 presents the probabilities of hits and false alarms in both English and Hebrew. As can be seen, there is indeed a dramatic difference in subjects' ability to detect transpositions in the two languages. Subjects' sensitivity to detection of transposition was relatively low in English material $\left(d^{\prime}=0.86\right)$, but it was very high for Hebrew material $\left(d^{\prime}=2.51\right)$. A paired $t$ test reveals this difference to be significant $[t(27)=7.0, p<.001, d=2.34]$.

\section{DISCUSSION}

The present study examined the impact of letter transposition on word reading in Hebrew-English bilinguals, using RSVP. Our results show a marked difference in the effect of letter transposition in the two languages. For English materials, the report of words was virtually unaltered when sentences included words with transposed letters. More importantly, subjects' ability to merely detect the letter transpositions was relatively low. Since each sentence contained three words with transposed letters, and the detection of any of these words was enough to provide a correct "yes" response in the detection-oftransposition task, the relatively low $d^{\prime}$ values obtained in English materials suggest an impressive resiliency of the perceptual system to letter transpositions in this language. For about one third of our subjects, detection of transpositions in English materials was at chance level. To borrow the expression employed in RSVP research some two decades ago demonstrating "repetition blindness" (e.g., Kanwisher \& Potter, 1990), our findings from English seem to suggest some kind of "transposition blindness" in English, at least following brief presentation. This finding seems to converge with recent results reporting strong masked-priming effects with transposed letters. However, the results obtained in English stand in sharp contrast to those obtained in Hebrew. The correct report of Hebrew words dropped dramatically in sentences containing transpositions, and $d^{\prime}$ values were exceedingly high. Since the participants in the present study were bilingual subjects in a within-subjects design, the difference between the Hebrew and the English blocks can only be attributed to a linguistic origin, not to experimental procedures, or to individual differences between the speakers of the two languages. Moreover, as performance in English and in Hebrew was very similar with normal sentences, the poor performance with transposed stimuli cannot be attributed to content complexity; rather, this reflects a genuine difference in sensitivity to transposition in the two languages.

What then is the source of the dramatic cross-linguistic differences in the impact of letter transposition on reading? Our findings suggest that effects of letter transposition probably reflect the principles of defining lexical space and lexical organization, and do not emerge from the peripheral registering of letters in alphabetic orthographies. In a recent study, Frost et al. (2005) argued that lexical space in Hebrew is organized in a radically different manner than that of English and other Indo-European languages. Whereas in English, words in the mental lexicon are aligned according to some orthographic dimension that registers their constituent letters, in Hebrew, lexical space is structured according to the morphological roots, so that all words derived from a given root are clustered together. If lexical access in a language such as Hebrew indeed requires the correct identification of a specific root morpheme, and many roots share the same set of letters, the primary task of the lexical system is to determine the exact identity and order of letters constituting the root morpheme. Root-letter transpositions will therefore prevent the processing system from extracting the correct root identity necessary for the lexical search. This would produce genuine differences in sensitivity to letter transpositions in Hebrew, when compared with English. Thus, whereas readers of English seem to display some "blindness" to transpositions in RSVP, readers of Hebrew seem to display extreme difficulties in reading transposed text. Support for this conclusion comes from recent reports by Friedmann and her colleagues showing that effects of letter-position dyslexia are significantly different for Hebrew and English materials (Friedmann \& Gvion, 2001, 2005). Hence, it seems that research at Hebrew University may produce quite different results than rscheearch at Cmabrigde Uinervtisy where visual word recognition is concerned. 


\section{AUTHOR NOTE}

This study was supported in part by National Institute of Child Health and Human Development Grant HD-01994 awarded to Haskins Laboratories. We thank Simon Liversedge for his contribution to earlier versions of this article. Correspondence concerning this article should be addressed to R. Frost, Department of Psychology, Hebrew University, Jerusalem, 91905 Israel (e-mail: frost@mscc.huji.ac.il).

\section{REFERENCES}

Christianson, K., Johnson, R. L., \& Rayner, K. I. (2005). Letter transpositions within and across morphemes. Journal of Experimental Psychology: Learning, Memory, \& Cognition, 31, 1327-1339.

Coltheart, M., Rastle, K., Perry, C., Langdon, R., \& Zeigler, J. (2001). DRC: A dual route cascaded model of visual word recognition and reading aloud. Psychological Review, 108, 204-256.

DAvis, M. (2003). "Aoccdrnig to a rscheearch." Personal web page via the Cognition \& Brain Sciences Institute, University of Cambridge. Retrieved April 24, 2006, from www.mrc-cbu.cam.ac.uk/ mattd/Cambrigde.

Deutsch, A., Frost, R., \& Forster, K. I. (1998). Verbs and nouns are organized and accessed differently in the mental lexicon: Evidence from Hebrew. Journal of Experimental Psychology: Learning, Memory, \& Cognition, 24, 1238-1255.

Friedmann, N., \& Gvion, A. (2001). Letter position dyslexia. Cognitive Neuropsychology, 18, 673-696.

FriedmanN, N., \& Gvion, A. (2005). Letter form as a constraint for errors in neglect dyslexia and letter position dyslexia. Behavioral Neurology, 16, 145-158.

Frost, R. (1995). Phonological computation and missing vowels: Mapping lexical involvement in reading. Journal of Experimental Psychology: Learning, Memory, \& Cognition, 21, 398-408.

Frost, R., Forster, K. I., \& Deutsch, A. (1997). What can we learn from the morphology of Hebrew?: A masked priming investigation of morphological representation. Journal of Experimental Psychology: Learning, Memory, \& Cognition, 23, 829-856.

Frost, R., Kugler, T., Deutsch, A., \& Forster, K. I. (2005) Orthographic structure versus morphological structure: Principles of lexical organization in a given language. Journal of Experimental Psychology: Learning, Memory, \& Cognition, 31, 1293-1326.
Grainger, J., \& van Heuven, W. J. B. (2003). Modeling letter position coding in printed word perception. In P. Bonin (Ed.), The mental lexicon: "Some words to talk about words" (pp. 1-23). New York: Nova Science.

Grainger, J., \& Whitney, C. (2004). Does the huamn mnid raed words as a whole? Trends in Cognitive Sciences, 8, 58-59.

Green, D. M., \& Swets, J. A. (1966). Signal detection theory and psychophysics. New York: Wiley.

Kanwisher, N. G., \& Potter, M. C. (1990). Repetition blindness: Levels of processing. Journal of Experimental Psychology: Human Perception \& Performance, 16, 1-30.

Lupker, S., \& Perea, M. (2003). Transposed-letter confusability effects in masked form priming. In S. Kinoshita \& S. J. Lupker (Eds.), Masked priming: State of the art (pp. 97-120). Hove, U.K.: Psychology Press.

McClelland, J. L., \& Rumelhart, D. E. (1981). An interactive activation model of context effects in letter perception: Part 1. An account of basic findings. Psychological Review, 88, 375-407.

ORnan, U. (2003). The final word: Mechanism for Hebrew word generation. Haifa: Haifa University Press.

Perea, M., \& Lupker, S. J. (2004). Can CANISO activate CASINO? Transposed-letter similarity effects with nonadjacent letter positions. Journal of Memory \& Language, 51, 231-246.

Potter, M. C. (1984). Rapid serial visual presentation (RSVP): A method for studying language processing. In D. E. Kieras \& M. A. Just (Eds.), New methods in reading comprehension research (pp. 91118). Hillsdale, NJ: Erlbaum.

Rawlinson, G. E. (1976). The significance of letter position in word recognition. Unpublished doctoral dissertation, University of Nottingham, Nottingham, England.

Rawlinson, G. E. (1999). Reibadailty. New Scientist, 162, 55.

Rayner, K., White, S. J., Johnson, R. L., \& Liversedge, S. P. (2006). Raeding wrods with jubmled lettrs: There's a cost. Psychological Science, 17, 192-193.

Schoonbaert, S., \& Grainger, J. (2004). Letter position coding in printed word perception effects of repeated and transposed letters. Language \& Cognitive Processes, 19, 333-367.

Whitney, C. (2001). How the brain encodes the order of letters in a printed word: The SERIOL model and selective literature review. Psychonomic Bulletin \& Review, 8, 221-243.

\section{APPENDIX}

Sentences in Which Letters in Target Words Have Been Transposed

\section{Hebrew Sentences}

1.

תחילת ההרשמה (ההרמשַה) לקורס התעכבה (התכעבה) בגלל המלחמה (המלמחה) הממושכת Registration for the course was delayed due to the lengthy war.

2

שחר וגיא מצֵאו (מאצו) את המחשבים (המשחבים) החדישים במזבַלה (במבזלה) הרחוקה Shahar and Guy found the state-of-the-art computers in the distant dumping site.

3. ח חברי המפלגה (המלפגה) הגדולה דרשַו (דשרו) לפטר את הפקחים (הפחקים) במועצות הדתיות The members of the major political party demanded that the Religious Council inspectors be fired.

4

תמר פגשה (פשגה) את האורחת החשובה ליד המזרקה (המרזקה) מול המסעדה (המעסדה) החדשה Tamar met the distinguished guest by the fountain adjacent to the new restaurant.

5

יעל ואיל מכרו (מרכַו) את הנעליים (הנלעיים) היקרות למשלחת (למלשחת) ללונדון Yael and Eyal sold the expensive shoes to the members of the delegation to London.

6

הועדה בדקה (בקדה) את המקור לתקלות (לתלקות) המוזרות במערכת (במרעכת) התחבורה The committee looked into the source of the strange technical failures in the transportation system.

7. שוטרי המקוף מפזרים (מזפַרים) כרגע הפגנה (הפנגה) בנוגע להתנחלות (להתחנלות) רביבים At the moment, the precinct policemen are breaking up the demonstration against the "R'vivim" settlement.

8 נועה רכשה (רשכהה) בחנות מסגרת (מגסרת) חדשה למשקפיים (למשפקיים) שלה Noa purchased new frames for her eyeglasses at the shop.

מיכל נזכרה (נזרכה) לקנות מדפסת (מדספת) חדישה ומקלדת (ומקדלת) תואמת Michal recalled that she was to buy a new printer as well as a matching keyboard.

10 השרים יפעלו (יפלעו) להוצאת מכרזים (מכזרים) לתפקידים בכירים במגזֵרים (במזגרֵים) השונים The ministers will work towards releasing tenders for executive positions in the various sectors.

11. אלון ולילך כתבו (כבתו) תסריט לסדרה (לסרדה) על מרגלים (מרלגים) רוסים Alon and Lilach wrote a script for a new television program about Russian spies. 


\section{APPENDIX (Continued)}

12. אלמונים דקרו (דרקו) את השחקנית (השקחנית) המפורסמת בדרכה למכבססה (למבכסהה) השכונתית) An unknown assailant stabbed the famous actress on her way to the local laundromat.

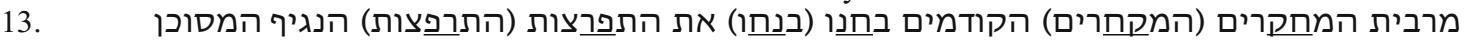
The majority of earlier studies examined the outbreak of the dangerous virus.

14. The gang members were charged yesterday for smuggling crates of cameras into Israel.

15. החיילים שמרו (שרמו) על המאגרים (המגארים) לשעת חירום במפקדה (במפדקה) הסודית The soldiers guarded the emergency reserves stored at the secret command center.

נ1ציג הממשלה (הממלשה) הנבחר הוזמן (הוממזן) לדיון בנוגע להפסָים (להפדסים) בהצבעות האחרונות ניגממת

The elected government representative was invited to a debate regarding the defeats in recent votes. 17. The security guards captured the assassin after chasing him down the busy street. 18. את הרקדן (הרדקן) הידוע בתור למרפאה (למראפה) החדשה (לת street. Yaron and Ro'i pushed the well-known dancer in the line at the new clinic.

19.

The Israeli and the worker got married on the stairs leading to the registration department. 20 הבלשים נקראו (נקארו) לדיון על ביצוע האזזנות (הזאנות) בלתי מאושרות במרכזיית (במרזכַיית)

המפלגה הבליה

The detectives were summoned to a debate regarding the unauthorized bugging of the political party's switchboard.

\section{English Sentences}

1. The journey (jounrey) was cancelled (cacnelled) because we forgot (fogrot) our tickets.

2. The surgeon (sugreon) told Jim not to disturb (ditsurb) his bandaged (badnaged) arm.

3. The scientist (scietnist) decided to decline (delcine) the invitation to lecture (letcure) next month.

4. My sister (sitser) accused me of lifting (litfing) some skirts (skitrs) from her closet.

5. We moved the furniture (funriture) and the carpet (capret) before we started (statred) to paint.

6. Your computer (copmuter) should automatically identify (idetnify) your printer (pritner) now.

7. The students (studetns) are protesting (protetsing) against raising dormitory (domritory) prices.

8. They had not intended (intedned) on entering (etnering) the jungle (jugnle) without a guide.

9. Bill ordered (odrered) a hamburger (hambugrer) from the girl at the corner (conrer) register.

10. I could not understand (undertsand) the information (infomration) posted on the billboards (billboadrs) overhead.

11. The guards (guadrs) are testifying (tetsifying) against the purse (pusre) thieves.

12. My company (copmany) is constantly consulting (consutling) various marketing (makreting) specialists.

13. The candidate (cadnidate) will not be elected (eletced) due to his problem (prolbem) with alcohol.

14. Sara asked (aksed) how to get to the restaurant (retsaurant) beside the farmer's (famrer's) market.

15. The board agreed (argeed) on three monuments (monumetns) for the county (coutny) square.

16. The parliament (palriament) cannot determine (detemrine) the regulations for emergency (emegrency) procedures.

17. We wanted (watned) to visit the library (lirbary) in the center (cetner) of the capital.

18. Workers were not permitted (pemritted) to enter the building (buidling) without appropriate (approrpiate) tools.

19. The nurse's (nusre's) aide instructed (instrutced) Susan to step behind the curtain (cutrain) for a checkup. 20. Employment conditions (codnitions) must be adjusted (adjutsed) before the winter (witner) sale. 